\title{
Responses of Falsemesquite, Native Grasses and Forbs, and Lehmann Lovegrass after Spraying with Picloram
}

\author{
S. CLARK MARTIN AND HOWARD L. MORTON
}

\begin{abstract}
Aqueous sprays of picloram at the rate of $0.56 \mathrm{~kg} / \mathrm{ha}(941 / \mathrm{ha}$ total volume) were applied to 5 plots each in May 1973 and August 1976 to control falsemesquite (Calliandra eriophylla) in southern Arizona. Falsemesquite was effectively controlled on both spraying dates. The greatest vegetation change on sprayed and unsprayed plots alike was the overwhelming natural increase in density and yield of Lehmann lovegrass, an introduced species. Perennial forbs were almost completely eliminated and densities of native perennial grasses were greatly reduced both on treated and untreated plots.
\end{abstract}

This report presents the results of a 5-year study (1972-1977) to determine the responses of perennial grasses following control of falsemesquite (Calliandra eriophylla) with aqueous sprays of picloram. Since falsemesquite is highly regarded as browse plant, why attempt to control it? Our thinking was that, although its leaves are both palatable and

Martin is principal range scientist, Rocky Mountain Forest and Range Experiment Station, Forestry Sciences Laboratory at Tempe, in cooperation with Arizona State University, Station's central headquarters is maintained at Fort Collins, in cooperation with Colorado State University. Morton is research leader, Rangelands Weed and Brush Control, U.S. Department of Agriculture, Science and Education Administration, Tucson, 85719.

Manuscript received November 8, 1978 nutritious, the value of falsemesquite as emergency forage is relatively low because the leaves drop off in winter and during severe drought. Also, since perennial grass stands often are sparse and of low vigor where falsemesquite is abundant, we suspected that falsemesquite might compete seriously with perennial grasses.

The study was conducted on the Santa Rita Experimental Range, $50 \mathrm{~km}$ south of Tucson, Arizona, at 1,160 m elevation, where average annual precipitation is about $380 \mathrm{~mm}$. Sixty percent of the year's moisture falls between June and September. The study area slopes gently downward to the northwest but is otherwise almost flat. Soil is White House gravelly sandy loam stony phase (Youngs et al. 1936). Youngs indicated that erosion was not serious on this soil because of protection by surface rocks and good grass cover. Data collected near the study site from 1968 to 1974 show that perennial grass herbage production was only $14 \mathrm{~kg} / \mathrm{ha}$, less than half as much as on another site having comparable rainfall but less falsemesquite and a different soil (Martin and Ward 1976).

The study layout consisted of fifteen $30-\mathrm{m}$ square plots in five 3-plot blocks. Aqueous sprays of picloram at the rate of $0.56 \mathrm{~kg} / \mathrm{ha}$ acid equivalent in $941 / \mathrm{ha}$ total volume were 
Table 1. Yearly and long-time average seasonal precipitation $(\mathrm{mm})$ at White House rain gauge, $1 \mathrm{~km}$ east of the study site.

\begin{tabular}{lccc}
\hline & \multicolumn{3}{c}{ Season or period } \\
\cline { 2 - 4 } Year & Oct. -May & June-Sept. & Year (Oct. - Sept.) \\
\hline $1972-73$ & 302 & 109 & 411 \\
$1973-74$ & 73 & 283 & 356 \\
$1974-75$ & 161 & 187 & 348 \\
$1975-76$ & 119 & 299 & 418 \\
$1976-77$ & 141 & 194 & 335 \\
5-year average & 159 & 214 & 373 \\
Average (1922-77) & 163 & 240 & 403 \\
\hline
\end{tabular}

applied with a tractor mounted boom sprayer. Five plots were sprayed in the spring (May 1973), five in the summer (August 1976), and five were not treated. The summer treatment was delayed until 1976 because summer growth of the falsemesquite was too poor to justify spraying in 1973, 1974, or 1975. Pretreatment measurements, in 1973, included density of herbaceous and woody plants on $1000.1 \cdot \mathrm{m}^{2}$ subplots along each of three $10 \mathrm{~m}$ long transects located $4.6 \mathrm{~m}$ apart near the center of each plot. Remeasurements were made in the fall of 1977. Sample plots clipped in March 1978 provided estimates of herbage production in 1977.

Rainfall from October 1972 through September 1977 was slightly below average for the period but was marked by an unusually wet October-May 1972-73, as well as by the driest 12-month period since 1924 from June 1973 through May 1974 (Table 1). Summer rainfall in 1974 and 1976 was well above average but was slightly below average in 1975 and

Table 2. Density (plants $/ \mathrm{m}^{2}$ ) of grasses, and (percent of plots $\left[0.1 \mathrm{~m}^{2}\right]$ without perennial vegetation) forbs and shrubs before treatment (1973) and in 1977.

\begin{tabular}{|c|c|c|c|c|c|c|}
\hline \multirow[b]{3}{*}{ Species } & \multicolumn{6}{|c|}{ Picloram spray } \\
\hline & \multicolumn{2}{|c|}{ Spring } & \multicolumn{2}{|c|}{ Summer } & \multicolumn{2}{|c|}{ Check } \\
\hline & 1973 & 1977 & 1973 & 1977 & 1973 & 1977 \\
\hline \multicolumn{7}{|l|}{ Perennial grasses } \\
\hline Aristida spp. & 2.47 & 0 & 1.67 & 0.00 & 3.20 & 0.20 \\
\hline Astrebla spp. & 0.87 & 1.47 & 0 & $\mathbf{0}$ & 0 & $\mathbf{0}$ \\
\hline Bouteloua chondrosioides & 19.07 & 6.40 & 11.27 & 6.20 & 12.13 & 6.80 \\
\hline Bouteloua curtipendula & 0.20 & 0.27 & 0 & 0 & 0 & 0 \\
\hline Bouteloua filiformis & 2.93 & 1.93 & 3.67 & 1.73 & 3.33 & 1.73 \\
\hline Bouteloua hirsuta & 16.00 & 6.27 & 12.60 & 3.07 & 21.60 & 6.47 \\
\hline tis lehmanniana ${ }^{1}$ & 5.00 & 57.53 & 11.67 & 92.80 & 5.00 & 77.27 \\
\hline Heter & 0.33 & 0.07 & 0.13 & 0.73 & 0.60 & 0.33 \\
\hline Leptoloma cognatum & 0.53 & 0 & 0.20 & 0.20 & 0.07 & 0 \\
\hline Lycurus phleoides & 0.80 & 0 & 0.40 & 0 & 0.33 & 0.13 \\
\hline Trichachne californica & 1.33 & 1.00 & 1.13 & 0.40 & 2.07 & 0.40 \\
\hline Total perenr & 49.53 & 74.94 & 42.741 & 05.13 & 48.33 & 93.33 \\
\hline \multicolumn{7}{|l|}{ Perennial forbs } \\
\hline Ambrosia psilostachya & 18.47 & $\mathbf{0}$ & 16.00 & $\mathbf{0}$ & 4.13 & 0 \\
\hline pusilla & 6.00 & 0 & 6.27 & 0.07 & 7.00 & 0.53 \\
\hline Evolvulus arizonicus & 2.47 & 0.33 & 2.33 & 0.27 & 4.20 & 0.40 \\
\hline Sida procumbens & 1.80 & 0.20 & 0.47 & 0.93 & 0.13 & 0.80 \\
\hline Solanum eleagnifolium & $\mathbf{0}$ & 0 & 0.67 & 0 & 0.73 & 0.20 \\
\hline Total perennial forbs & 28.73 & 0.53 & 25.73 & 1.27 & 16.20 & 1.93 \\
\hline \multicolumn{7}{|l|}{ Shrubs } \\
\hline Carlowrightia arizonica & 1.33 & 0.13 & $\mathbf{0}$ & 0.27 & 0.20 & 0.13 \\
\hline Calliandra eriophylla ${ }^{1}$ & 48.80 & 0.73 & 41.60 & 0.60 & 53.87 & 24.07 \\
\hline Aplopappus tenuisectus & 0.07 & $\mathbf{0}$ & 0.80 & 0 & 0 & 0.07 \\
\hline Mimosa dysocarpa & $\mathbf{0}$ & 0 & $\mathbf{0}$ & 0 & 0.20 & 0 \\
\hline Prosopis juliflora var. velutina & $\mathbf{0}$ & 0 & 0.13 & 0.07 & 0 & \\
\hline Total shrubs & 50.20 & 0.87 & 42.53 & 0.94 & 54.47 & 24.27 \\
\hline
\end{tabular}

' Differences among treatments in 1977 significant at $5 \%$ level as determined by analysis of covariance.
1977. Thus, the study period included seasons of high, low, and average precipitation.

Pretreatment differences in vegetation between plots assigned to the different treatments were mostly small or nonsignificant. Perennial grasses were generally low in vigor. Sprucetop grama (Bouteloua chondrosioides) and hairy grama ( $B$. hirsuta) were the most abundant species, Lehmann lovegrass (Eragrostis lehmanniana) was third (second on summer spray plots), and three-awn (Aristida spp.) was fourth (Table 2). Western ragweed (Ambrosia psilostachya) was the most abundant forb followed by ayenia (Ayenia pusilla) and Arizona evolvulus (Evolvulus arizonicus). Falsemesquite was the dominant shrub. The fact that Lehmann lovegrass, an exotic perennial, had become a major species by natural spread in 1973 suggested that it might continue to increase at the expense of native species, as reported by Cable (1971 and 1976).

Remeasurement in 1977 showed that the density of falsemesquite on sprayed plots had been reduced by $98 \%$. The spring (1973) and summer (1976) sprays of picloram were almost equally effective.
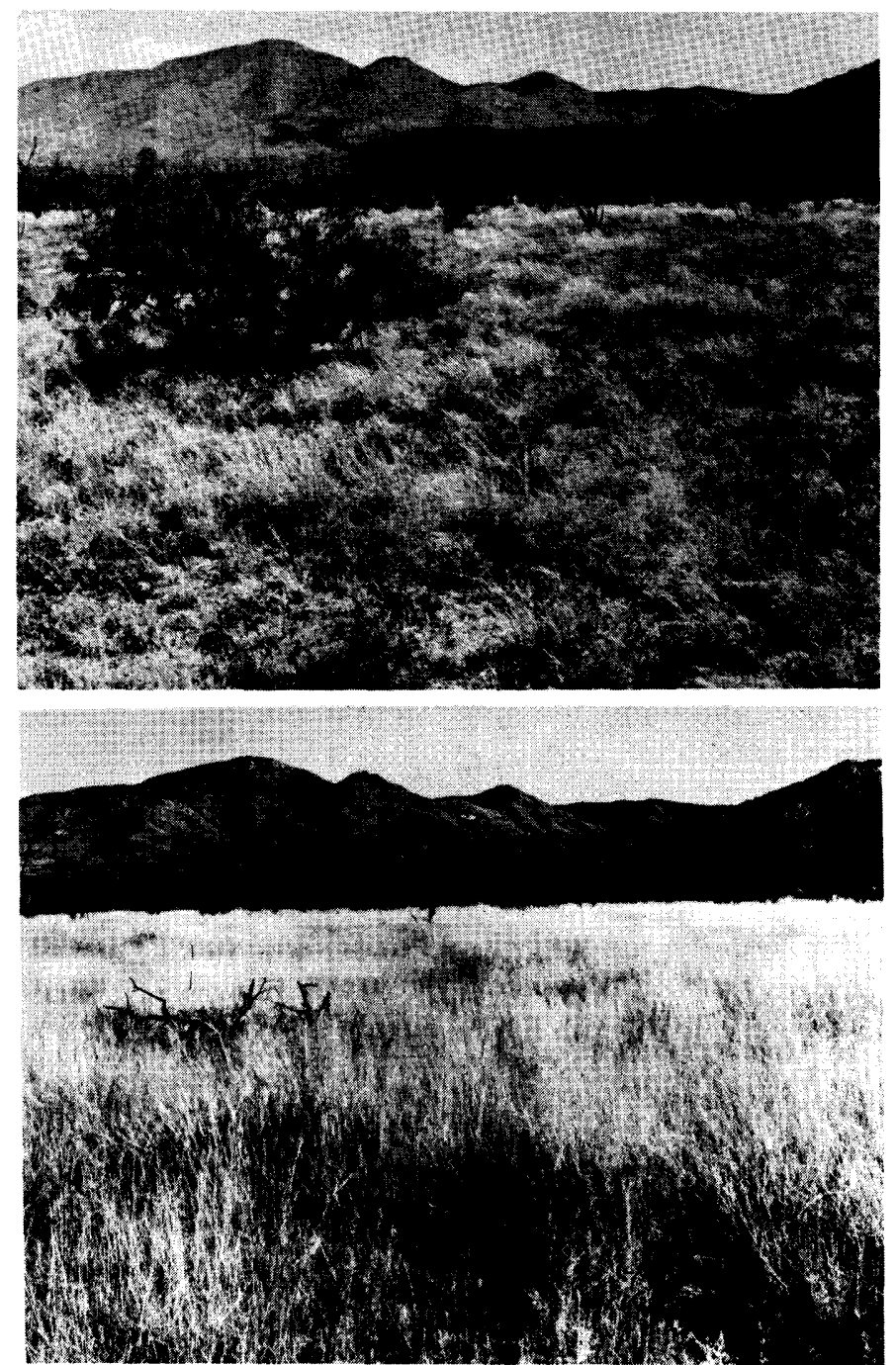

Fig. 1. Typical view of the study area. (A.) 1973 before treatment showing relatively sparse grass cover and vigorous stand of false mesquite. (The smal mesquite tree was removed to facilitate spraying). (B.) 1977 showing almost complete dominance of Lehmann lovegrass. 

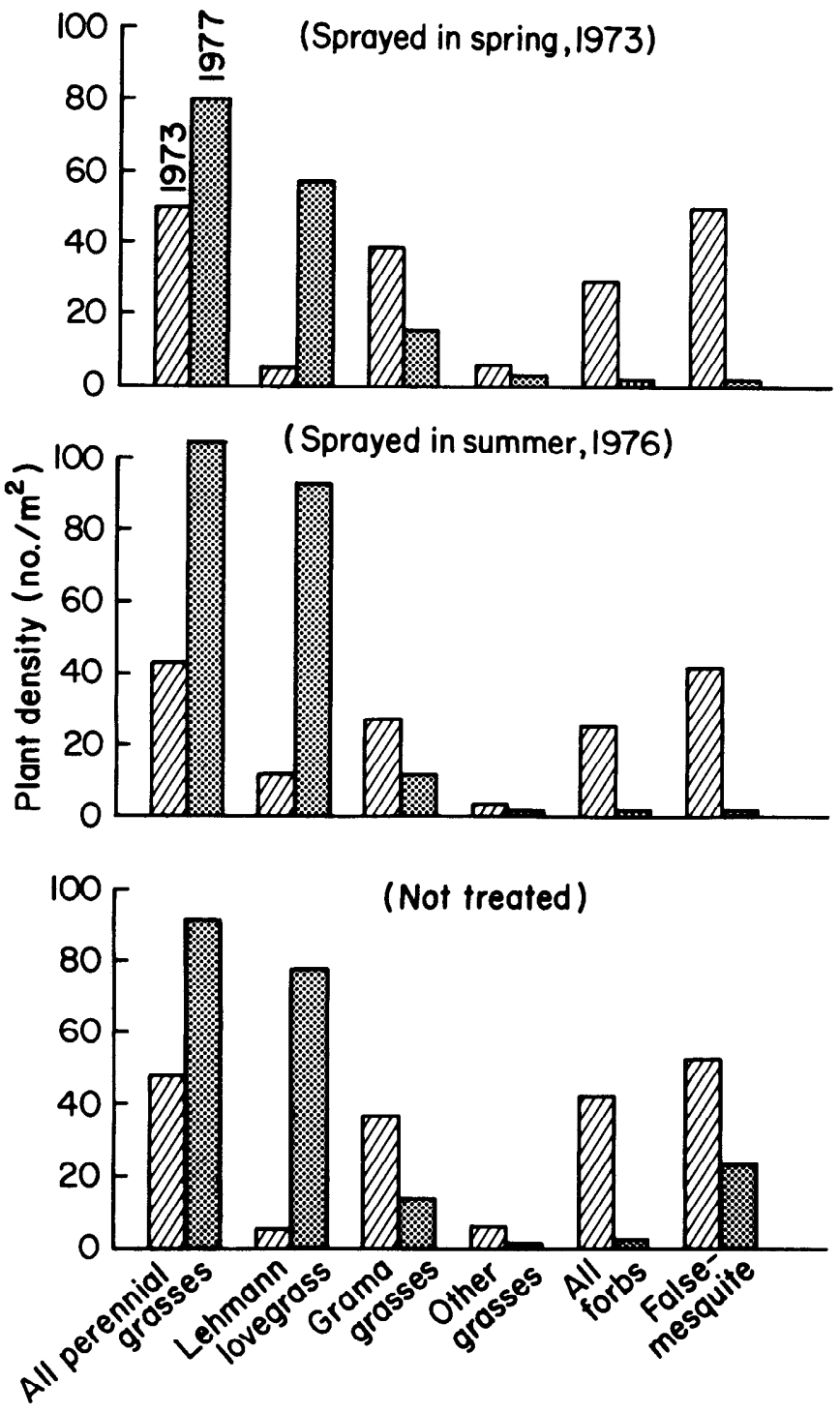

Fig. 2. Densities (plants $/ \mathrm{m}^{2}$ ) for major species or plant groups in 1973 and 1977.

The most spectacular vegetation change was the manifold increase in Lehmann lovegrass on all plots (Fig. 1). The increases in lovegrass were accompanied by sharp decreases in most other species, as Cable (1971 and 1976) reported for other areas on the Santa Rita (Table 2). Gains in Lehmann lovegrass more than offset the losses in native perennial grasses, so that total perennial grass densities in 1977 were 1.5 to 2.5 times greater than before treatment. Meanwhile, total forb densities declined from 16 to 29 per $^{2}$ in 1976 to 2 or less in 1977. None of the forbs increased.

The other unexpected vegetation change was that falsemesquite lost $55 \%$ of its density on the unsprayed plots. This
Table 3. Perennial grass standing herbage (kg/ha) March, 1978 (1977 forage crop).

\begin{tabular}{lcccc}
\hline Treatment & $\begin{array}{c}\text { Grama } \\
\text { grasses }\end{array}$ & $\begin{array}{c}\text { Lehmann } \\
\text { lovegrass }\end{array}$ & $\begin{array}{c}\text { Other } \\
\text { grasses }\end{array}$ & Total $^{1}$ \\
\hline $\begin{array}{l}\text { Sprayed } \\
\text { May 1973 }\end{array}$ & 43 & $2437 \mathrm{ab}$ & 134 & $2614 \mathrm{ab}$ \\
$\begin{array}{l}\text { Sprayed } \\
\text { August 1976 }\end{array}$ & 74 & $3012 \mathrm{a}$ & 71 & $3157 \mathrm{a}$ \\
None & 146 & $1647 \mathrm{~b}$ & 32 & $1825 \mathrm{~b}$ \\
\hline
\end{tabular}

${ }^{1}$ Numbers in a column not followed by the same letter differ significantly at the $5 \%$ level.

suggests that Lehmann lovegrass not only thrives in the presence of falsemesquite but that it can compete vigorously with it. Lehmann lovegrass and falsemesquite both draw heavily on cool-season moisture, and the fact that mature lovegrass is about twice as tall as falsemesquite may place the shrub at a disadvantage.

Lehmann lovegrass, which made up only 10 to $27 \%$ of the perennial grass density in 1973, made up 77 to $88 \%$ in 1977 . These increases in density of lovegrass were accompanied by increases in herbage production. Yields of perennial grass in 1977 ranged from 1,825 to $3,157 \mathrm{~kg} / \mathrm{ha}(1,629 \mathrm{lb} /$ acre $-2,819$ lb/acre) (Table 3) compared to yields of $214 \mathrm{~kg} / \mathrm{ha}$ (191 lb/acre) reported for a nearby area before Lehmann lovegrass takeover (Martin and Ward 1976). These changes in yield and species composition, though desirable for cattle, may make the range less desirable for wildlife species that prefer forbs and browse to grass.

Any responses of native perennial grasses to control of falsemesquite were obscured by the overwhelming increases in Lehmann lovegrass. The density of Lehmann lovegrass in 1977 was higher on plots sprayed in the summer of 1976 than on those sprayed in the spring of 1973. Initial densities were not significantly different. Standing herbage of lovegrass in March 1978 was greatest on plots sprayed in the summer of 1976 and least on untreated plots (Table 3).

Results of the study suggest that: (1) picloram is effective for controlling falsemesquite, and (2) the 8- to 15-fold increase in grass production due to the natural increase in Lehmann lovegrass suggests that lovegrass can increase herbage yields on areas of White House soil where native perennial grasses now produce very little.

\section{Literature Cited}

Cable, Dwight R. 1971. Lehmann lovegrass on the Santa Rita Experimental Range, 1937-1968. J. Range. Manage. 24:17-21.

Cable, Dwight R. 1976. Twenty years of changes in grass production following mesquite control and reseeding. J. Range Manage. 29:286-289.

Martin, S. Clark and Donald E. Ward. 1976. Perennial grasses respond inconsistently to alternate year seasonal rest. J. Range Manage. 29:346.

Youngs, F.O., A.T. Sweet, A.T. Strahorn, T.W. Glassey and E.N. Poulson. 1936. Soil survey of the Tucson Area, Arizona. USDA Bur. Chem. and Soil Ser. 1931, No. 19. 60 p. 